[Agr. Biol. Chem., Vol. 34, No. 11, p. 1646 1651, 1970]

\title{
Ethylene Formation from Acrylic Acid by a Banana Pulp Extract ${ }^{\dagger}$
}

\author{
By Keishi SHImokawa and Zenzaburo KaSAI \\ The Research Institute for Food Science, \\ Kyoto University, Kyoto \\ Received April 23, 1970
}

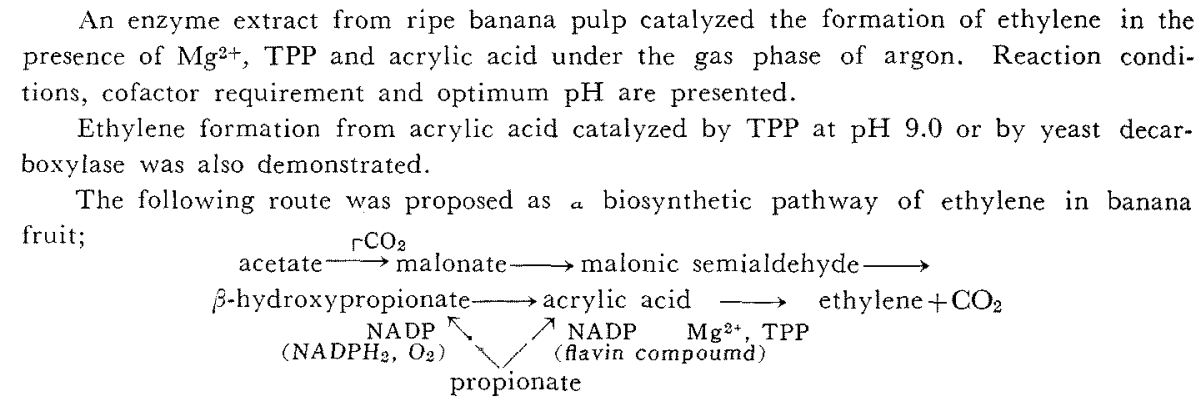

In previous reports, ${ }^{1,2 !}$ a pathway of ethylene formation from acetate $-2-{ }^{14} \mathrm{C}$ and propionate$2-{ }^{14} \mathrm{C}$ in banana pulp slices and homogenates has been proposed.

However, direct proof on the final step of the proposed pathway-decarboxylation of acrylic acid-has not been obtained. The present paper describes the formation of ethylene from acrylic acid catalyzed by an enzyme extract obtained from banana pulp, non-enzymatic production of ethylene catalyzed by TPP and the evolution of ethylene catalyzed by yeast pyruvate decarboxylase.

\section{MATERIALS AND METHODS}

Materials. Unripe (green) banana fruits (Musa

t A part of this report was presented at the Annual Meeting of the Agricultural Chemical Society of Japan, Fukuoka, April 1970.

1) K. Shimokawa and Z. Kasai, Agr. Biol. Chem., 34, 1633 (1970).

2) K. Shimokawa and Z. Kasai, ibid., 34, 1640 (1970)

Abbreviation used in this paper: TPP, thiamine pyrophosphate. sapientum L.) were obtained from Kyoka Co., Ltd. at the Central Market in Kyoto City. They were ripened by keeping them in desiccator at $20^{\circ} \mathrm{C}$. Pulp of yellow banana (at the climacteric rise) was used as a material. Pyruvate decarboxylase was obtained from Boehringer, Mannheim, Germany. Acrylic acid was purchased from Nakarai Chemicals Co., Kyoto.

Assay conditions. Protein was determined by the method of Warburg and Christian. ${ }^{3 i}$ Ethylene was determined by gas chromatography as shown in the previous report.11

Preparation of enzyme extract. Pulp of banana, yellow in their peel color, was cooled at $5 \mathrm{C}$ for $2 \sim 3$ $\mathrm{hr}$, then ground in ice-cold $0.1 \mathrm{M}$ potassium phosphate buffer, pH 7.0 in a mortar. The homogenates were squeezed through gauze and centrifuged at $100,000 \mathrm{~g}$, for $20 \mathrm{~min}$, at $5^{\circ} \mathrm{C}$. Table I shows the distribution of activity of ethylene formation from acrylic acid in the homogenate, supernatant and sediment. To the supernatant was added solid ammonium sulphate ( 390 $\mathrm{mg} / \mathrm{ml}, 60 \%$ ) and adjusted to $\mathrm{pH} 7.0$. The protein precipitated was collected by centrifugation and dis-

3) O. Warburg and W. Christian, Biochem. Z, 310, 384 (1941). 
TABle I. Distribution OF Ethylene-Forming ACTIVITY IN HoMOgENATES, SUPERNATANT AND SEDIMENTS

\begin{tabular}{lcc}
\multicolumn{1}{c}{ Fraction } & $\begin{array}{c}\mathrm{C}_{2} \mathrm{H}_{4} \\
(\mathrm{~m} \mu \mathrm{l})\end{array}$ & $\begin{array}{c}\text { Specific activity } \\
(\mathrm{m} \mu \mathrm{l} / \mathrm{mg} \text { protein) }\end{array}$ \\
\hline Homogenates & 122.4 & 5.05 \\
Supernatant & 72.0 & 4.50 \\
Sediments & 26.4 & 2.54
\end{tabular}

The reaction mixture contained $3 \mathrm{ml}$ of either homogenates, supernatant or sediments $(4.84,3.20$ and $2.08 \mathrm{mg}$ protein per $\mathrm{ml}$, respectively), $400 \mu$ moles of potassium phosphate buffer, $\mathrm{pH} 7.0,3 \mu$ moles of acrylic acid, $100 \mu$ moles of $\mathrm{MgSO}_{4}, 10 \mu$ moles of TPP, in a total volume of $4 \mathrm{ml}$. Incubation time, $60 \mathrm{~min}$; Incubation temp., $30^{\circ} \mathrm{C}$; Gas phase: argon.

solved in $0.1 \mathrm{M}$ potassium phosphate buffer, $\mathrm{pH} 7.0$, and dialyzed against the same buffer for $24 \mathrm{hr}$, with three changes of the buffer. Any precipitate formed during the dialysis was removed by centrifugation and the resulting supernatant was used as the enzyme extract.

Assay of enzyme activity. To test the activity of the enzyme extract to catalyze ethylene production, the following reaction mixture was used: $3 \mu \mathrm{l}$ ( $36 \mathrm{~m} \mu$ moles) of acrylic acid, $100 \mu$ moles of $\mathrm{MgSO}_{4}, 10 \mu$ moles of thiamine pyrophosphate, 400 amoles of potassium phosphate buffer, $\mathrm{pH} 7.0$, and a suitable amount of the enzyme extract $(4.6 \mathrm{mg}$ protein $/ \mathrm{ml}$ ) in a total volume of $4 \mathrm{ml}$. The reaction was carried out in a $50 \mathrm{ml}$ Erlenmeyer flask at $30^{\circ} \mathrm{C}$. The reaction was started by injecting acrylic acid with microsyringe. Because of the instability of aqueous solution of acrylic acid, it was added directly without dilution. The flask was flowed by argon or by air, and was bubbled first in $20 \% \mathrm{KOH}$ and secondly in $0.25 \mathrm{M}$ mercuric perchlorate. After the incubation, the mercuric perchlorate adsorbed ethylene was transferred into the sealed flask, and ethylene was released by adding of $4 \mathrm{M}$ lithium chloride. The atmosphere containing ethylene in each flask was sampled with a hypodermic syringe, and ethylene was determined by gas chromatography under the same conditions described previously. ${ }^{11}$

\section{RESULTS}

\section{Identification of ethylene}

After the incubation in the presence of

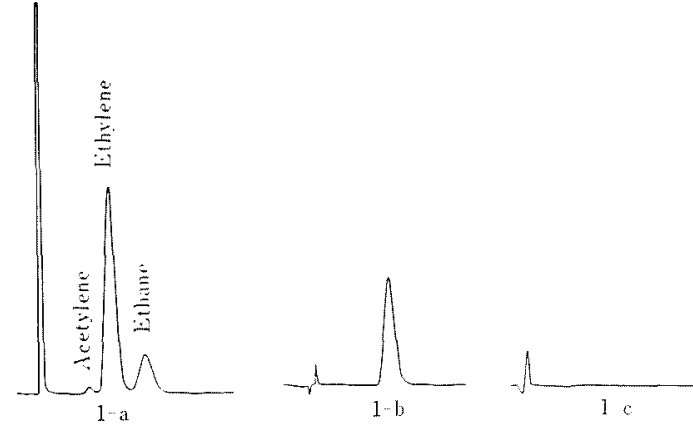

FIG. 1. Identification of Ethylene by Gas Chromatography.

1-a. Gas chromatogram of standard acetylene, ethylene and ethane.

1-b. Gas chromatogram of gas sample obtained from reaction mixture in the presence of $\mathrm{Mg}^{2+}$, TPP, acrylic acid and the enzyme extract.

1-c. Gas chromatogram after absorbent-treatment of the mixture containing acetylene and the gas sample used in 1-b.

Gas chromatography was carried out as described previously. ${ }^{1\}}$

$\mathrm{Mg}^{2+}$, TPP, the enzyme extract and acrylic acid as a substrate, the gas sample of the reaction vessel was analyzed by gas chromatography. As shown in Fig. 1, ethylene was identified by comparison of the retention time with that of authentic ethylene and by cochromatography with the standard ethylene $\left(99.99^{\circ}\right)$ ). This was also supported from the evidence that the gas in the reaction vessel was absorbed by the specific absorbent (Absorite-PM, Tokyo Kasei Co, Ltd.) for unsaturated hydrocarbons (Fig. 1-c). Any other hydrocarbons was not recognized in the space of the reaction vessel.

Co-factor requirement for ethylene formation from acrylic acid

For the ethylene formation from acrylic acid by the enzyme extract, the presence of TPP and gas phase of argon were required (Table II). When the complete system was incubated under air or oxygen, the formation of ethylene was not observed. Ethylene for- 
Table II. Co-factor Requirement for Ethylene FORMATION FROM ACRYLIC ACID BY THE ENZYME EXTRACT

\begin{tabular}{llr} 
Gas phase & \multicolumn{1}{c}{ System } & $\begin{array}{c}\text { Ethylene } \\
(\mathrm{m} \mu \mathrm{l})\end{array}$ \\
Argon & & \\
& Complete & 47.5 \\
& minus $\mathrm{Mg}^{2+}$ & 37.5 \\
& minus TPP & 7.6 \\
& minus $\mathrm{Mg}^{2+}$ and TPP & 5.0 \\
& minus acrylic acid & 3.5 \\
& with boiled enzyme extract & $<1.0$ \\
Oxygen & Complete & $<1.0$ \\
Air & & $<1.0$
\end{tabular}

The complete system contained $3 \mathrm{ml}$ of the enzyme extract, 400 pmoles of potassium phosphate buffer, $\mathrm{pH} 7.0,3 \mu$ of acrylic acid, $100 \mu$ moles of $\mathrm{MgSO}_{4}$, 10 umoles of TPP in a total volume of $4 \mathrm{ml}$. Incubation time; $10 \mathrm{~min}$. Incubation temp; $30^{\circ} \mathrm{C}$.

mation was not detected in the case of the boiled enzyme extract, even in the presence of acrylic acid, $\mathrm{Mg}^{2+}$ and TPP. This fact indicates that the formation of ethylene from acrylic acid proceeds enzymatically. Requirement for an argon gas phase might be due to the protection of acrylic acid from its oxidation and polymerization.

\section{Effect of $p H$}

The optimum $\mathrm{pH}$ for the formation of acrylic acid from acrylic acid by the enzyme extract was 7.0 (Fig. 2).

\section{Time course of ethylene formation}

The relationship between ethylene formation and time was determined using the standard conditions described previously. Ethylene formation increased with time for $10 \mathrm{~min}$, and after that the rate decreased. Ethylene was reproduced, however, by the further addition of acrylic acid, as shown in Fig. 3.

\section{Effect of enzyme concentration}

Figure 4 shows an observation indicating a

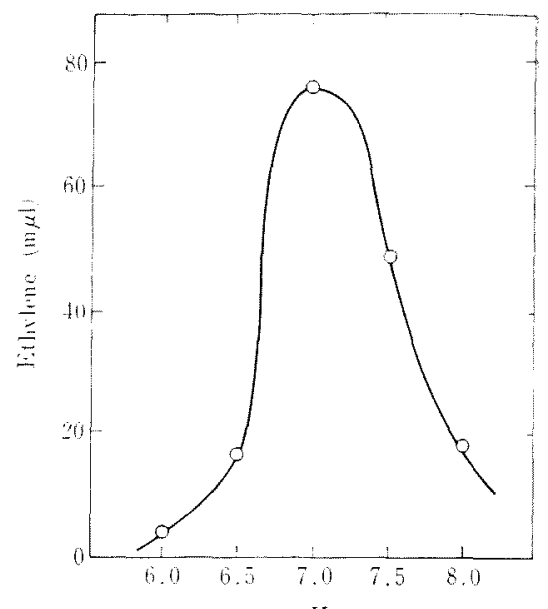

FIG. 2. Effect of $\mathrm{pH}$ on Ethylene Formation from Acrylic Acid by the Enzyme Extract.

The reaction mixture contained $3 \mathrm{ml}(14 \mathrm{mg}$ protein) of the enzyme extract, $400 \mu$ moles of potassium phosphate buffer ( $\mathrm{pH}$ as indicated), $3 \mu$ moles of acrylic acid, $100 \mu$ moles of $\mathrm{MgSO}_{4}, 10 \mu$ moles of TPP in a total volume of $4 \mathrm{ml}$. Incubation. time; $10 \mathrm{~min}$. Incubation temp; $30^{\circ} \mathrm{C}$.

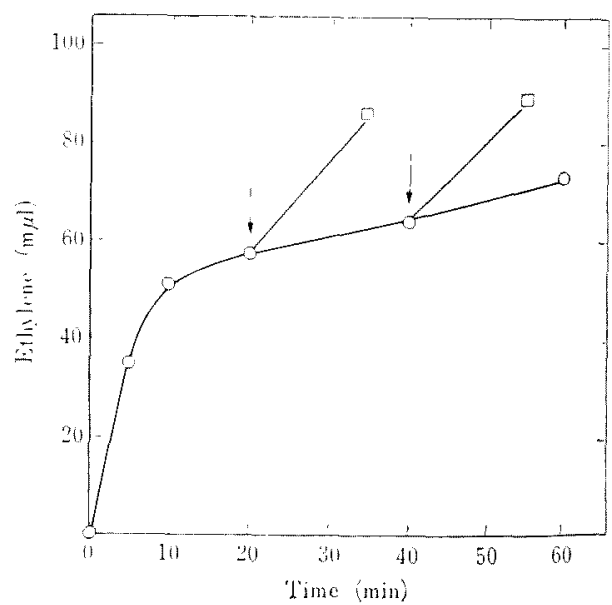

FIG. 3. Time Course of Ethylene Formation from Acrylic Acid by the Enzyme Extract.

The assay conditions were described in Materials and Methods.

Arrows indicate that acylic acid $(3 \mu \mathrm{l})$ was supplied in the reaction mixture at this time. 


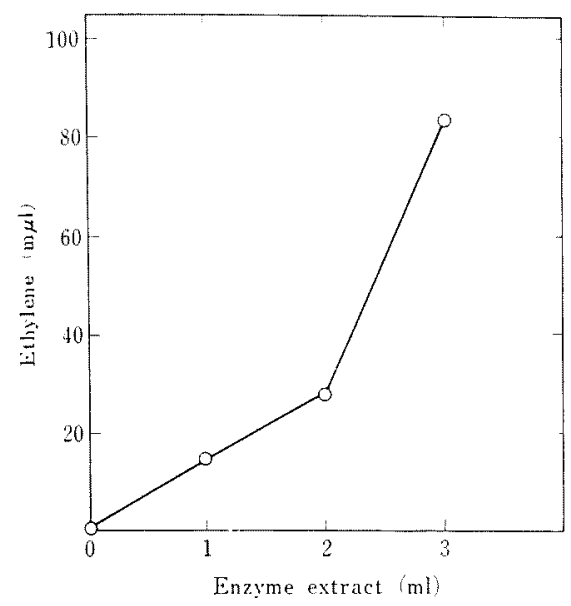

FIG. 4. Effect of the Enzyme Extract Concentration on Ethylene Formation from Acrylic Acid.

The assay conditions were described in Materials and Methods. One $\mathrm{ml}$ of the enzyme extract contained $4.6 \mathrm{mg}$ protein. Reaction time; $10 \mathrm{~min}$.

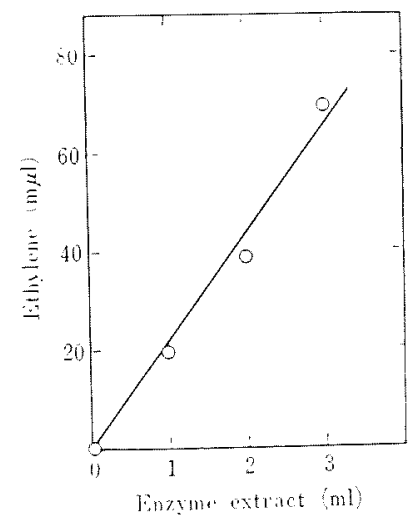

Fig. 5. Effect of Bovine Serum Albumin on Ethylene Formation from Acrylic Acid in Enzyme Extract.

The assay conditions were the same as that described in Materials and Methods, except the addition of $4 \mathrm{mg}$ bovine serum albumin.

Incubation time: $10 \mathrm{~min}$.

lack of linearity between the rate of formation and the enzyme concentration. This fact suggests that there was a damage of the enzyme protein by acrylic acid, for example, as observed by Cavins, "through the reaction with the $\mathrm{SH}$-group of the enzyme. This was supported by the observation that the linearity was obtained when bovine serum albumin was added to the reaction mixture (Fig. 5).

\section{Effect of acrylic acid concentration}

Ethylene formation increased with increasing concentration of acrylic acid up to $3 \mu \mathrm{l}$ in the reaction mixture (Fig. 6 ). High concentration

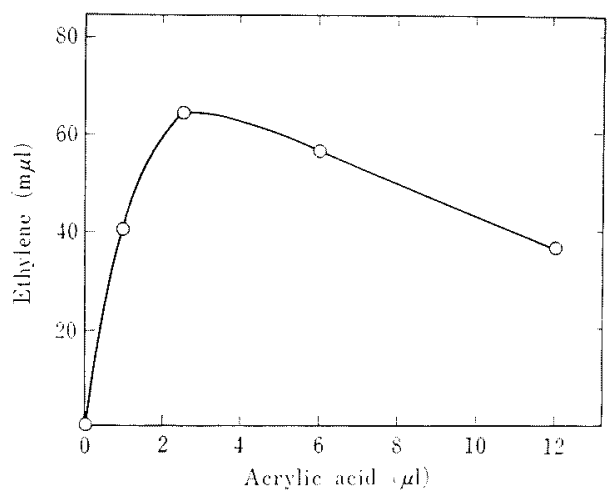

FIG. 6. Effect of Substrate Concentration on Ethylene Formation in the Enzyme Extract.

The assay conditions were described in Materials and Methods. The enzyme extract in the reaction mixture contained $12 \mathrm{mg}$ protein.

of acrylic acid caused reduction in rate of ethylene formation. Approximately $K m$ for acrylic acid is $7 \times 10^{-3} \mathrm{M}$. The failure ${ }^{51}$ to enhance ethylene formation with acrylic acid, may result from the toxity for the enzyme protein at high concentration.

Non-enzymatic formation of ethylene from acrylic acid in the presence of $\mathrm{Mg}^{2}$ and TPP

As described above, it is possible that ethylene was formed by decarboxylation of acrylic acid. The occurrence of non-enzymatic

4) J. F. Carins and M. Friedman, J. Biol. Chem., 243, 3357 (1968).

5) M. Meheriuk and M. Spencer, Phytochem., 6, 551 (1967). 
Table III. Non-enzymatic Formation of Ethylene FROM ACRYLIC ACID IN THE PRESENCE OF $\mathrm{Mg}^{2+}$ AND TPP

\begin{tabular}{lc} 
System & Ethylene $(\mathrm{m} \mu \mathrm{l})$ \\
\hline Complete & 27 \\
minus acrylic acid & 0 \\
minus $\mathrm{Mg}^{2+}$ & 0 \\
minus $\mathrm{TPP}^{2+}$ & 0 \\
minus $\mathrm{Mg}^{2+}$ and TPP & 0
\end{tabular}

The complete system contained $200 \mu$ moles of sodium borate buffer, $\mathrm{pH} 9.0,3 \mu \mathrm{l}$ of acrylic acid, $100 \mu$ moles of $\mathrm{MgSO}_{4}, 10 \mu$ moles of TPP in a total volume of 2 $\mathrm{ml}$. Incubation time; $60 \mathrm{~min}$. Incubation temp; $37^{\circ} \mathrm{C}$. The gas phase was argon.

decarboxylation of pyruvate in the presence of TPP has been well known. ${ }^{61}$ This nonenzymatic reaction should assist in understanding the biological ethylene formation in the presence of $\mathrm{Mg}^{2+}$ and TPP. Therefore, an attempt to demonstrate the non-enzymatic formation in a model system containing TPP and acrylic acid was carried out. Table III shows that at $\mathrm{pH} 9$ ethylene was formed from acrylic acid in the presence of TPP without any enzyme extract. For non-enzymatic formation a high $\mathrm{pH}$ was required, while the $\mathrm{pH}$ optimum of the enzymatic formation by banana pulp extracts was found to be $\mathrm{pH} 7.0$ as shown previously. It is believed that this is another evidence to support participation of decarboxylation in the final step of ethylene formation from acrylic acid.

Ethylene formation from acrylic acid by yeast pyruvate decarboxylase

The decarboxylation of acrylic acid presented above has similar properties to the decarboxylation of pyruvate in the requirement for TPP. ${ }^{6}$ Therefore, it is expected that pyruvate decarboxylase also catalyzes the decarboxyla-

6) S. Mizuhara, R. Tamura and H. Arata, Proc. Japan Acad., 27, 302 (1951); S. Mizuhara and K. Ōno, ibid., 27, 705 (1951); E. Yatco-Manzo, F. Roddy, R. G. Yount and D. E. Metzler, J. Biol. Chem., 234, 733 (1959).
TABLE IV. ETHYLENE FORMATION FROM ACRYLIC ACID By Yeast Pyruvate DeCarboXylase

\begin{tabular}{lc} 
System & Ethylene $(\mathrm{m} \mu \mathrm{l})$ \\
\hline Complete & 12 \\
minus acrylic acid & 0 \\
minus TPP & 9 \\
minus $\mathrm{Mg}^{2+}$ & 0 \\
minus enzyme & 0 \\
with boiled enzyme & 0
\end{tabular}

The complete system contained $20 \mu \mathrm{g}$ of yeast p) ruvate decarboxylase which catalyzes the decarbox lation of $0.4 \mu$ moles of pyruvate at $25^{\circ} \mathrm{C}, 200 \mu \mathrm{mole}$ of potassium phosphate buffer, $\mathrm{pH} 7.0,100 \mu$ mole of $\mathrm{MgSO}_{4}, 10 \mu$ moles of TPP, $3 \mu \mathrm{L}$ of acrylic acid an $2 \mathrm{mg}$ of bovine serum albumin in a total volume o $3 \mathrm{ml}$. Incubation time; $10 \mathrm{~min}$. Incubation temp $30^{\circ} \mathrm{C}$. The gas phase was argon.

tion of acrylic acid. Table IV shows th formation of ethylene from acrylic acid $b$ : yeast pyruvate decarboxylase in the presenci of $\mathrm{Mg}^{2+}$ and TPP. Without the enzym ethylene was not formed at neutral $\mathrm{pH} \mathrm{em}$ ployed in this experiment by using the enzym extract from the banana pulp.

\section{DISGUSSION}

In the previous report, a possible pathway of ethylene formation in banana pulp slices and homogenates was proposed. In this pathway, the final step is a decarboxylation of acrylic acid. The decarboxylation of acrylic acid as the biosynthetic sequence of ethylene has been proposed by Wang et al. ${ }^{\text {" }}$ and Spencer et al. ${ }^{51}$ Wang et al." observed the incorporation of $\mathrm{C}-2$ and $\mathrm{C}-3$ of acrylic acid, but not $\mathrm{C}-1$, into ethylene using specific labeled acrylic acid in Penicillium digitatum. Spencer et $a l .^{5}$ also proposed the participation of acrylic acid decarboxylation to the formation of ethylene from their results indicating that ethylene formation from $\beta$-alanine was

7) C. H. E. Wang, A Persyn and J. Krackor, Nature, 195, 1306 (1962); D. W. Jacobsen and C. H. Wang, Plant Physiol., 40 (suppl), xix (1965). 
enhanced in the enzyme extract obtained from bean cotyledons. But they showed that acrylic acid was inhibitory in endogeneous ethylene formation from tomato tissues. Under these circumstances, the present paper is a first demonstration of enzymatic formation of ethylene from acrylic acid. The failure of the enhancement of ethylene formation by adding acrylic acid by Spencer et al..$^{51}$ may resulted from the oxidation of the acid by oxygen and a damage of the enzyme by the acid because the gas phase in their experiment was air.

Mapson and Wardale ${ }^{8 !}$ found that ethylene formation from methional by an enzyme system from cauliflower florets was optimum at $\mathrm{pH}$ 6.6. Shimokawa and $\mathrm{Kasai}^{9}$ found $\mathrm{pH}$ 6.0 was optimum for the formation of ethylene from pyruvate by a subcellular fraction from apple tissues, and $\mathrm{Yang}^{10}$ found a $\mathrm{pH}$ range from 7.3 to 8.3 was optimum for the conversion of methional to ethylene by horseradish peroxidase. More recently, Stinson and Spencer ${ }^{12}$ recognized the presence of two peaks, at $\mathrm{pH} 7.0$ and 8.5 , for optimum ethylene formation from $\beta$-alanine in the presence of TPP by an enzyme extract from bean cotyledons. Endogeneous formation of ethylene from apple tissues was also recognized at high $\mathrm{pH}^{131}$ For the enzymatic formation of ethylene from acrylic acid by the banana enzyme extract, $\mathrm{pH} 7.0$ was optimum. In contrast to this, the non-enzymatic formation of ethylene in the presence of TPP was observed at high $\mathrm{pH}$. The ethylene formation at the high $\mathrm{pH}$ reported by Stinson and Spencer suggests the participation of nonenzymatic ethylene formation catalyzed by TPP, as found in the present experiments.

The physiological significance of the ethylene formation by yeast pyruvate decarboxylase remains to be evaluated. However, it should be attended that the activity of pyruvate decarboxylase rise with ripening of some fruits after harvest and with its rising of the activity ethylene formation increase as recognized in various fruits. ${ }^{14,151}$

No ethylene formation from acrylic acid was found in the presence of horseradish peroxidase instead of banana enzyme extract. This fact indicates that the present biosynthesis sequence is to be different from ethylene biosynthesis by oxidative degradation of methionine. ${ }^{16)}$

Finally we wish to propose the following route as a biosynthetic pathway of ethylene in banana fruits.

$$
\text { acetate } \stackrel{\mathrm{CO}_{2}}{\longrightarrow} \text { malonate } \longrightarrow \text { malonic semialdehyde } \longrightarrow \beta \text {-hydroxypropionate } \longrightarrow \text { acrylic acid } \stackrel{\mathrm{Mg}^{2+}, \mathrm{TPP}}{\longrightarrow} \text { ethylene }+\mathrm{CO} 2
$$

8) L.W. Mapson and D. A. Wardale, Biochem. J., 102, $574(1967)$.

9) K. Shimokawa and Z. Kasai, Plant Cell Physiol., 8, $227(1967)$.

10) S. F. Yang, Arch. Biochem. Biohpys., 122, 481 (1967).

11) T. Takeo and M. Lieberman, Biochem. Biophys, Acta, 178, 235 (1969).

12) A. Stinson and M. Spencer, Plant Physiol., 44, 1217 (1969).
13) M. Liberman, A. T. Kunishi, L. W. Mapson and D. A. Wardale, Plant Physiol., 41, 376 (1966).

14) A. C. Hulme, J. D. Jones and L. S. C. Wooltorton, Proc. Roy. Soc. Lond. Ser. B, 158, 519 (1963).

15) K. Shimokawa and Y. Ueda, Unpublished data.

16) L. W. Mapson, Biol. Rev., 44, 155 (1969). 